\title{
QUALITY OF LIFE IN PATIENTS WITH NARCOLEPSY
}

\section{A WHOQOL-Bref study}

\author{
Heloísa Rovere', Sueli Rossini', Rubens Reimão ${ }^{3}$
}

\begin{abstract}
Objective: To evaluate the perception of Quality of Life (QL) in Brazilian patients with narcolepsy. Method: 40 adult patients aged between 20 and 72 years (mean=41.55; SD=14.50); (28 F; 12M), with the diagnosis of chronic narcolepsy were followed up at the outpatient clinic (Patient Group). The Control Group was composed of 40 adults. The instrument utilized was the World Health Organization Quality of Life (WHOQOLBREF). Results: The two groups were homogeneous and no difference was found with regards to age, sex, and demographic characteristics. The perception of QL in physical, psychological and social domains showed lower scores in those patients with narcolepsy than in the control group $(p<0.05)$. Concerning physical domain, all the aspects evaluated were significantly impaired, in patient group, including sleep satisfaction $(p<0.001)$; energy for daily activities $(p=0.039)$; capacity to perform activities $(p=0.001)$; and capacity to work $(p=0.001)$. Conclusion: The perception of QL showed severe impairment in patients with narcolepsy for physical, psychological and social domains.
\end{abstract}

KEY WORDS: narcolepsy, sleep, sleep disorders, quality of life.

\section{Qualidade de vida de pacientes com narcolepsia: um estudo de WHOQOL-Breve}

Resumo - Objetivo: Avaliar a percepção de qualidade de vida (QV) em pacientes com narcolepsia. Método: 40 pacientes com idades de 20 a 72 anos (média 41,55; desvio padrão=14,50); (28 F; $12 \mathrm{M}$ ), com diagnóstico de narcolepsia, crônica, seguidos em ambulatório (Grupo Paciente). O Grupo Controle foi composto de 40 adultos. O instrumento utilizado foi o Instrumento de Qualidade de Vida da Organização Mundial de Saúde (WHOQOLBREF). Resultados: Os dois grupos foram homogêneos e não foram encontradas diferenças de idade, sexo e características demográficas. A percepção da QV nos domínios físico, psicológico e social mostrou escores menores nos pacientes com narcolepsia do que no Grupo Controle $(p<0,05)$. Quanto ao domínio físico, todos os aspectos avaliados foram significantemente comprometidos, no grupo paciente, como a satisfação com o sono $(p<0,001)$; energia para as atividades diárias $(p=0,039)$; capacidade de desempenhar atividades $(p=0,001)$; e capacidade de trabalho $(p=0,001)$. Conclusão: A percepção de $Q V$ mostrou comprometimento acentuado nos pacientes com narcolepsia, nos domínios físico, psicológico e social.

PALAVRAS-CHAVE: narcolepsia, sono, distúrbios do sono, qualidade de vida.

Narcolepsy is a neurological disease characterized by excessive daytime sleepiness which is often difficult to resist. It was systematically described by the French neurologist Jean Batiste Gelineau in 1888, as presenting abnormal sleep and excessive daytime sleepiness. Cataplexy was added in 1902, as another manifestation of narcolepsy'. The main symptom of narcolepsy is excessive daytime sleepiness that can put the patient at risk while performing activities such as driving and operating certain machines as well as during other actions requiring concentration. Also, narcolepsy sufferers may present difficulties in their work activities at school or even at home. Diag- nosis may be difficult initially as there are several symptoms similar to other diseases and often these patients visit a number of medical specialists before reaching the definitive diagnosis ${ }^{2,3}$.

Recent studies in animal models and man have shown that narcolepsy is a degenerative disease due to the lack of Orexin (also called Hypocretin) - a stimulant neurotransmitter - in the lateral hypothalamus ${ }^{4}$.

The objective of this research was to evaluate the perception of Quality of Life (QL) in patients with narcolepsy by means of the instrument World Health Organization Quality of Life (WHOQOL-BREF) $)^{5}$. This research is part of

Sleep Medicine Advanced Research Group, Division of Clinical Neurology, Hospital das Clinicas, University of Sao Paulo Medical School, Sao Paulo, SP, Brazil: 'Social Worker; ${ }^{2}$ Psychologist, PhD; ${ }^{3}$ Neurologist, MD, PhD.

Received 25 October 2007, received in final form 28 January 2008. Accepted 5 March 2008.

Dr. Rubens Reimão - Rua dos Bogarís 38 - 04047-020 São Paulo SP - Brasil. E-mail: reimaorubensneuro@yahoo.com 
a larger project of the authors on narcolepsy to be published elsewhere ${ }^{6-10}$.

\section{METHOD}

We evaluated 40 adults subjects aged from 20 to 72 years (mean 41.55; standard deviation, SD=14.50), comprising $28 \mathrm{fe-}$ males and 12 males, with the diagnosis of chronic narcolepsy and followed up at the Neurology Department outpatient clinic. The diagnosis had been based on standard clinical, polysomnographic and Multiple Sleep Latency Test ${ }^{11}$.

The Control Group was composed of 40 hospital workers or volunteers aged from 20 to 80 years (mean 42.8; SD=15.96), comprising 30 women and 10 men. The Control Group only included individuals with fixed daytime work schedules, presenting no chronic diseases or sleep disorders.

The evaluation was performed through individual interviews utilizing standardized questionnaires, after the patient had signed the Informed Consent Term. The data collection was performed by the first author and the sample was considered sequentially. The interviews were applied using questionnaires and held at the Outpatient Clinic HC FMUSP. The mean time for applying the questionnaires was one hour.

The WHOQOL-BREF is a generic instrument for the perception of QL easy to appy and may be used in different social groups. It was developed by the World Health Organization with international objectives and has been applied in several countries $^{8}$.

The WHOQOL-BREF is composed of 26 questions, distributed into four domains. Each domain considers several aspects: A) Physical Domain: pain/discomfort/energy/fatigue/sleep/ rest; B) Psychological Domain: feelings/appearance self esteem/ memory and concentration; C) Social Relations Domain: social relations/social support/sexual activity; D) Environment Domain: safety/home environment/finances/leisure/transport/ social care.

\section{Statistics}

The present study evaluated 80 individuals including 40 patients with narcolepsy (Patient Group) and controls without narcolepsy (Control Group). Statistical analysis employed the ChiSquare test and the Fisher Exact Test. To compare QL scores in groups the Mann-Whitney nonparametric test was used, and to verify if scales were related, the chi-Square homogeneity index was used to investigate the association between socio-economic aspects and perception of QL for both groups separately. For all the tests utilized, the significance level of $5 \%$ was applied. The statistical Package for Social Sciences, Windows Program, version 10.0 (SPSS) was used for statistical analysis of data.

\section{Ethics}

This research was approved on February 2003 by the Ethics Committee of the institution, Hospital das Clinicas da FMUSP under Research Protocol \#032/03. All patients and controls signed the Informed Consent Term at the beginning of the evaluation.
Table 1. Age, years of schooling, and family income in patients and controls.

\begin{tabular}{lccc}
\hline $\mathrm{N}$ & $\begin{array}{c}\text { Narcolepsy } \\
\text { Age }\end{array}$ & $\begin{array}{c}\text { Controls } \\
40\end{array}$ & $\mathrm{P}$ \\
$\quad$ Mean & & & \\
$\mathrm{SD}$ & 41.85 & 42.78 & \\
Minimum & 14.50 & 15.96 & 0.889 \\
Maximum & 20 & 21 & \\
Schooling (years) & 72 & 80 & \\
Mean & & & \\
SD & 10.45 & 11.53 & \\
Minimum & 3.71 & 3.17 & 0.200 \\
Maximum & 4 & 3 & \\
Family income & 15 & 16 & \\
(Minimum Wage) & & & \\
Mean & & & \\
SD & 6.73 & 7.03 & \\
Minimum & 4.95 & 3.73 & 0.390 \\
Maximum & 0 & 2 & \\
\hline
\end{tabular}

$\mathrm{p}=$ Mann-Whitney test.

\section{RESULTS}

Demographic data for study and control groups

The age, years of schooling and family income of both groups is shown in Table 1. There was no statistically significant difference between the two groups, being homogeneous for socio economic and demographics data.

There was no statistically significant difference between patients with narcolepsy and controls in relation to age, schooling years or family income.

We noted that there were no significant differences in relation to the social-economic profile in the Patient Group and the Control Group in relation to gender, religion, marital status, family composition and kind of housing (Table 2).

However, significant statistical differences were found in relation to occupational state, in which more subjects from the study Group were found not to be holding jobs than the Control Group ( $p=0.018)$, and also in relation to socio-economic classification, where the Study Group showed lower scores compared do Control Group $(p=0.049)$.

\section{QL Perception}

Table 3 shows that the perception of QL in physical, psychological and social domains presented statistically lower scores in patients with narcolepsy $(p<0.05)$, whereas no difference in Environment was evidenced ( $p=0.239)$.

Table 4 shows some items in the WHOQOL-BREF and the perception of QL and the physical domain. All the questions on physical domain showed statistically signif- 
Table 2. Demographic and social-economic characteristics.

\begin{tabular}{|c|c|c|c|c|}
\hline & Category & Narcolepsy & Controls & $\mathrm{p}$ \\
\hline \multirow[t]{2}{*}{ Gender } & Female & $70.0 \%$ & $75.0 \%$ & 0.617 \\
\hline & Male & $30.0 \%$ & $25.0 \%$ & \\
\hline \multirow[t]{6}{*}{ Religion } & Catholic & $40.0 \%$ & $57.5 \%$ & 0.421 \\
\hline & Evangelical & $25.0 \%$ & $20.0 \%$ & \\
\hline & Spiritualist & $10.0 \%$ & $7.5 \%$ & \\
\hline & Budist & $7.5 \%$ & $0.0 \%$ & \\
\hline & Jewish & $5.0 \%$ & $2.5 \%$ & \\
\hline & No religion & $12.5 \%$ & $12.5 \%$ & \\
\hline \multirow[t]{4}{*}{ Marital status } & Maried & $55.0 \%$ & $37.5 \%$ & 0.333 \\
\hline & Bachelor & $35.0 \%$ & $40.0 \%$ & \\
\hline & Widow & $5.0 \%$ & $12.5 \%$ & \\
\hline & Separated & $5.0 \%$ & $10.0 \%$ & \\
\hline \multirow[t]{8}{*}{ Occupation } & No occupation & $17.5 \%$ & $0.0 \%$ & 0.018 \\
\hline & Employed & $40.0 \%$ & $70.0 \%$ & \\
\hline & House wife & $10.0 \%$ & $7.5 \%$ & \\
\hline & Retired due to disability & $2.5 \%$ & $0.0 \%$ & \\
\hline & Caregiver & $12.5 \%$ & $0.0 \%$ & \\
\hline & Retired & $10.0 \%$ & $10.0 \%$ & \\
\hline & Self-employed & $5.0 \%$ & $7.5 \%$ & \\
\hline & Student & $2.5 \%$ & $5.0 \%$ & \\
\hline \multirow[t]{4}{*}{ Family members } & 0 a 2 & $22.5 \%$ & $32.5 \%$ & 0.187 \\
\hline & 3 a 4 & $47.5 \%$ & $45.0 \%$ & \\
\hline & 5 a 6 & $27.5 \%$ & $12.5 \%$ & \\
\hline & $>6$ & $2.5 \%$ & $10.0 \%$ & \\
\hline \multirow[t]{3}{*}{ Housing } & Owner & $60.0 \%$ & $82.5 \%$ & 0.097 \\
\hline & Rented & $30.0 \%$ & $10.0 \%$ & \\
\hline & Lent & $10.0 \%$ & $7.5 \%$ & \\
\hline \multirow[t]{4}{*}{ Social economic status } & Bottom lower & $17.5 \%$ & $2.5 \%$ & 0.049 \\
\hline & Upper lower & $55.0 \%$ & $47.5 \%$ & \\
\hline & Lower middle & $27.5 \%$ & $47.5 \%$ & \\
\hline & Middle & $0.0 \%$ & $2.5 \%$ & \\
\hline
\end{tabular}

$\mathrm{p}=$ Chi-Square.

Table 3. Perception of quality of life in the narcolepsy group and the control group.

\begin{tabular}{llcccc}
\hline Domains & Group & Mean & SD & Median & P \\
\hline Physical & Narcolepsy & 48.93 & 15.67 & 48.21 & $<0.001$ \\
& Control & 74.02 & 15.30 & 71.43 & \\
Psychological & Narcolepsy & 56.04 & 14.74 & 56.25 & \\
& Control & 72.81 & 13.51 & 75.00 & $<0.001$ \\
Environment & Narcolepsy & 50.16 & 15.32 & 46.88 & \multirow{2}{*}{0.239} \\
& Control & 54.92 & 15.79 & 56.25 & \\
Social & Narcolepsy & 60.83 & 17.11 & 58.33 & \\
& Control & 73.13 & 14.31 & 75.00 & 0.001 \\
\hline
\end{tabular}

$\mathrm{p}=$ Chi-Square.

icant difference regarding the perception of satisfaction with sleep $(p<0.001)$, lack of energy to perform daily activities $(p=0.039)$, capacity to perform activities $(p=0.001)$ and capacity to work ( $p=0.001)$.

Regarding the perception of QL reported by the sub- jects from the Narcolepsy Group, we observed lower percentages in the categories described as "good" or "very good". While subjects in the control group described less categories as "very bad" or "bad" in reporting their perception of $Q L(p=0.019)$. 
Table 4. Perception of quality of life and physical domain variables in narcolepsy group and control group.

\begin{tabular}{|c|c|c|c|c|}
\hline QL and physical domain & Category & Narcolepsy & Control & $\mathrm{p}$ \\
\hline \multirow[t]{5}{*}{ Perception of quality of life } & Very bad & $10.0 \%$ & $0.0 \%$ & \\
\hline & Bad & $12.5 \%$ & $0.0 \%$ & \\
\hline & Regular & $37.5 \%$ & $37.5 \%$ & 0.019 \\
\hline & Good & $37.5 \%$ & $52.5 \%$ & \\
\hline & Very good & $2.5 \%$ & $10.0 \%$ & \\
\hline \multirow[t]{5}{*}{ Sleep satisfaction } & Very unsatisfied & $22.5 \%$ & $2.5 \%$ & \\
\hline & Unsatisfied & $45.0 \%$ & $10.0 \%$ & \\
\hline & Regular & $17.5 \%$ & $22.5 \%$ & $<0.001$ \\
\hline & Satisfied & $15.0 \%$ & $50.0 \%$ & \\
\hline & Very satisfied & $0.0 \%$ & $15.0 \%$ & \\
\hline \multirow{5}{*}{$\begin{array}{l}\text { Energy for daytime } \\
\text { activities }\end{array}$} & Null & $2.5 \%$ & $0.0 \%$ & \\
\hline & Very little & $27.5 \%$ & $7.5 \%$ & \\
\hline & Regular & $40.0 \%$ & $32.5 \%$ & 0.039 \\
\hline & Very often & $22.5 \%$ & $40.0 \%$ & \\
\hline & Fully & $7.5 \%$ & $20.0 \%$ & \\
\hline \multirow{5}{*}{$\begin{array}{l}\text { Capacity to perperform } \\
\text { activities }\end{array}$} & Very unsatisfied & $10.0 \%$ & $0.0 \%$ & \\
\hline & Unsatisfied & $27.5 \%$ & $7.5 \%$ & \\
\hline & Regular & $30.0 \%$ & $17.5 \%$ & 0.001 \\
\hline & Satisfied & $27.5 \%$ & $47.5 \%$ & \\
\hline & Very satisfied & $5.0 \%$ & $27.5 \%$ & \\
\hline \multirow[t]{5}{*}{ Capacity to work } & Very unsatisfied & $12.5 \%$ & $2.5 \%$ & \\
\hline & Unsatisfied & $35.0 \%$ & $10.0 \%$ & \\
\hline & Regular & $25.0 \%$ & $15.0 \%$ & 0.001 \\
\hline & Satisfied & $25.0 \%$ & $45.0 \%$ & \\
\hline & Very satisfied & $2.5 \%$ & $27.5 \%$ & \\
\hline
\end{tabular}

$\mathrm{p}=$ Chi-Square

\section{DISCUSSION}

The relationship between sleep disorders and perception of QL is also a subject of study among professionals in the health area, seeking to measure how sleep disorders affect the perception of patients and interfere with their environment, social relations, physical and psychological aspects $^{12-15}$.

The current study investigated the perception of $\mathrm{QL}$ in patients with narcolepsy by means of the WHOQOL-BREF instrument and compared results with subjects from a Control Group in order to verify if the presence of narcolepsy influences the perception of QL in these patients.

Domains in the QL evaluation of the WHOQOL-BREF encompass different aspects of daily life and provide the basis for evaluating the perception of satisfaction individuals in relation to their objective and subjective living conditions ${ }^{5}$.

The physical domain evaluated aspects were pain and discomfort, energy and fatigue, sleep and rest, daily life activities, dependence on medication or treatment and capacity to work.

The environment domain is related to physical safety and protection, financial resources, opportunities to acquire new information and abilities, capacities to participate, leisure opportunities as well as physical environment (pollution/noise/traffic/climate) and transport.

The psychological domain evaluates the presence of positive feelings, thought, learning, memory and concentration, self-esteem, corporal image and appearance while the social relation domain evaluates personal relations, social support and sexual activity.

In terms of the environment domain, there was only a slight difference. This may be due to the fact that the subjects in both Study and Control Groups presented homogeneous social and economic characteristics for number of schooling years, kind of housing, family composition and family income, thus suggesting that the environmental conditions in which they live were similar.

In regards to physical, psychological and social domains, we have found results similar to those international studies on QL and narcolepsy, in which the authors reported that patients with narcolepsy, compared to controls, presented lower scores across all studied domains ${ }^{12-15}$.

Ervick et al. ${ }^{13}$ evaluated health-related QL by means of the Medical Outcomes Study of Life Inventory ques- 
tionnaire (SF-36) in patients with narcolepsy. These authors verified that patients with narcolepsy presented lower scores for all evaluated domains, with more severe impairment in physical and social domains. The patients reported greater difficulty in concentration and work capacity, memory problems, and social conflicts due to the embarassment caused by the symptoms of narcolepsy.

The study by Teixeira et al. ${ }^{14}$ in the United Kingdom evaluated patients with narcolepsy and compared results with two groups of patients with Obstructive Sleep Apnea syndrome (SAOS) and a group treated with CPAP (Continuous Positive Airway Pressure). The QL perception and functional scale utilized the Outcomes of Sleep Questionnaire (FOSQ). Patients with narcolepsy showed lower scores in all domains versus the control groups. There was no difference between patients with narcolepsy and patients with SAOS without CPAP treatment. However, patients with narcolepsy presented lower scores on two domains of the SF-36 (mental health and general health) and on all FOSQ domains, showing more severe impairment in relation to work capacity than patients with SAOS using CPAP.

Vignatelli et al. ${ }^{15}$ from the University of Bologna, Italia, evaluated the health-related QL of patients with narcolepsy compared to patients with SAOS and patients with idiopathic hypersomnia, utilizing the SF-36 questionnaire. The patients with narcolepsy presented impairment in all domains except for body pain, with lower results than the Italian population at large. The results showed that narcolepsy impairs the QL with a deficit in physical and emotional functions. Excessive daytime sleepiness was the symptom of narcolepsy most impairing QL.

Daniels et al. ${ }^{12}$ assessed the health-related QL in patients with narcolepsy in the United Kingdom, Members of the United Kingdom Association of Narcolepsy, using the UK Short Form 36-F instrument, Beck's Depression Inventory and the Ullanlina Narcolepsy scale. Results showed that patients scored significantly lower on all eight domains of the SF- 36 .

The present study revealed that patients with narcolepsy perceived QL as impaired in all physical and psychological aspects while social relations were also severely impaired. The deficits were explained by the patients as being due to the narcolepsy symptoms, mainly excessive daytime sleepiness. Patients in our sample tended to attribute to the symptoms of narcolepsy to their indisposition and lack of energy to perform daily and work activities.
Women with narcolepsy commonly reported tiredness, fatigue and frequently irritability in performing home activities, which generated some degree of family conflict.

In conclusion, the perception of QL in patients with narcolepsy showed significantly lower scores in the physical ( $p<0.001)$, psychological $(p<0.001)$, and social $(p=0.001)$ domains than the Control Group. There was no difference between the two groups with regards to the environment domain $(p=0.029)$. More severe impairment in the physical domain due to symptoms of narcolepsy was observed, especially excessive daytime sleepiness, compromising both psychological and social domains. The items related to the physical domain, including unsatisfactory sleep, unsatisfactory capacity for daily activities, at home and at work, along with lack of energy for day-to-day activities were considered important factors impairing the general QL in narcoleptics. Narcolepsy led to QL impairment in physical and emotional functions negatively impacting family dynamics and work conditions.

\section{REFERENCES}

1. Schenck CH, Bassetti CL, Arnulf L, Mignot E. English translations of the first clinical reports on narcolepsy and cataplexy by Westphal and Gelineau in the late $19^{\text {th }}$ century, with commentary. J Clin Sleep Med 2007;3:301-311.

2. Goswami M. The influence of clinical symptoms on quality of life in patientw with narcolepsy. Neurology 1998;50:S31-S36.

3. Broughton WA, Broughton RJ. Psychosocial impact of narcolepsy. Sleep 1994;17(Suppl ): S45-S49.

4. Taheri S, Zeitler JM, Mignot E. the role of hypocretins (orexins) in sleep regulation and narcolepsy. Annu Rev Neurosci 2002; 25:283-303.

5. Fleck MPA, Leal CF, Louzada S, et al. Desenvolvimento da versão em português do instrumento de avaliação de qualidade de vida da OMS (WHOQOL-100). Rev Bras Psiquiatr 1999;21:19-28.

6. Adda C, Lefèvre B, Reimão R. Narcolepsy and depression. Arq Neuropsiquiatr 1998;56:650-654.

7. Cowan R, Reimão R, Lemmi H, Vander Zwagg R. Narcolepsia e início súbito de períodos REM após despertares. Arq Neuropsiquiatr 1985; 43:229-233.

8. Reimão R. Night sleep electroencephalogram power spectral analysis in excessive daytime sleepiness disorders. Arq Neuropsiquiatr 1991;49: 128-135.

9. Reimão R, Lemmi H. Narcolepsia e apnéia do sono concomitantes. Arq Neuropsiquiatr 1986;44:73-77.

10. Reimão R, Lemmi H. Narcolepsy in childhood and adolescence. Arq Neuropsiquiatr 1991;49:260-264.

11. International Classification of Sleep Disorders, revised edition. Rochester, American Sleep Disorders Association, 2001.

12. Daniels E, King MA, Smith IE, Shneerson JM.Health-related quality of life in narcolepsy. J Sleep Res 2001;10:75-81.

13. Ervic S, Abdelnoor M, Haier MS, Ramberg M, Strand G. Health-related quality of life in narcolepsy. Acta Neurol Scand 2006;114:198-204.

14. Teixeira VG, Faccenda JF, Douglas NJ. Functional status in patients with narcolepsy. Sleep Med 2004;5:477-483.

15. Vignatelli L, D'Alessandro R, Mosconi P et al. Health-related quality of life in Italian patients with narcolepsy: the SF-36 health survey. Sleep Med 2004;5:467-475. 